\title{
Differences in risk behaviours and HIV status between primary amphetamines and opioid injectors in Estonia and Russia
}

\author{
Authors: Isabel TAVITIAN-EXLEY ${ }^{1 *}$; Mathieu MAHEU-GIROUX ${ }^{2}$; Lucy PLATT³; \\ Robert HEIMER $^{4}$; Anneli UUSKÜLA ${ }^{5}$; Olga LEVINA ${ }^{6}$; Peter VICKERMAN ${ }^{7}$; Marie- \\ Claude BOILY ${ }^{1}$ \\ ${ }^{1}$ Department of Infectious Disease Epidemiology, Imperial College London, United Kingdom. \\ ${ }^{2}$ Department of Epidemiology, Biostatistics, and Occupational Health, McGill University, Montréal, Canada. \\ ${ }^{3}$ Department of Social and Environmental Health Research, London School of Hygiene and Tropical Medicine. \\ ${ }^{4}$ Epidemiology of Microbial Diseases, School of Public Health, Yale University, United States. \\ ${ }^{5}$ Department of Family Medicine and Public Health, University of Tartu, Estonia. \\ ${ }^{6}$ NGO Stellit, St Petersburg, Russian Federation \\ ${ }^{7}$ School of Social and Community Medicine, University of Bristol, United Kingdom. \\ *Corresponding Author: \\ Tavitianexley@gmail.com (i.tavitianexley09@imperial.ac.uk)
}

Submission category: Original research article

Running head: Amphetamine injection and HIV risk

Word count: 4,250 (excluding title page, references, figures and tables)

Keywords: HIV; risk behaviours; PWID; amphetamine injection; opioid injection; polydrug use; respondent-driven sampling.

Declaration of interest: None declared. 


\section{ABSTRACT}

\section{Background and objective}

People who inject drugs (PWID) account for over half of new HIV infections in Eastern Europe and central Asia, where opioids continue to be the dominant illicit drugs injected. Stimulants including amphetamines (ATS) have been associated with HIV infection risk in several settings. We sought to examine whether primary ATS injection was associated with greater HIV risk, compared to opioid injection in two European locales with significant HIV epidemics.

\section{Methods}

PWID in Kohtla-Järve and St. Petersburg were recruited in respondent driven sampling in 2012-2013. Survey data on demographic characteristics, service use, injecting and sexual risk behaviours, and HIV-status (and HCV in Kohtla-Järve) were compared between primary opioid and ATS injectors using logistic regression models.

\section{Results}

Of 591 injectors recruited in Kohtla-Järve and 811 in St. Petersburg, 195 (33\%) and 27 (4\%) primarily injected ATS in each city. In both cities, ATS injectors were younger than opioid injectors, initiated injection later, injected less frequently and were more likely to have been paid for sex. In both cities, PWID had high levels of multiple sex partners. In Kohtla-Järve, ATS-injectors had lower odds of back-loading and greater odds of polydrug use than opioid-injectors. In St. Petersburg, where over half of PWID reported unsafe sharing practices, ATS-injectors were less likely to report these practices. ATS-injection was negatively associated with being HIV positive in KohtlaJärve (aOR=0.6; 95\%CI: 0.5-0.8) and St. Petersburg (aOR=0.3; 95\%CI: 0.1-0.7). ATSinjection was negatively associated with $\mathrm{HCV}$-reactivity in Kohtla-Järve (aOR=0.5; 95\%CI: 0.3-0.6).

\section{Conclusions}

In both locations, primary ATS injection was associated with lower injecting risk behaviours, lower HIV status and being paid for sex compared to opioid injection. Targeted services are needed for ATS injectors, to increase contact with interventions and reduce sexual and injecting risk. Harm reduction services, including sexual risk reduction, need to be expanded for all PWID in St. Petersburg. 


\section{INTRODUCTION}

People who inject drugs (PWID) were estimated to account for $51 \%$ of new human immunodeficiency virus (HIV-1) infections in Eastern Europe and central Asia in 2014, a region with the fastest growing HIV epidemic associated with injection drug use globally (United Nations Joint Programme on AIDS, 2016; United Nations Office on Drugs and Crime, 2016).

Opioid injection has been the main driver of HIV epidemics in Estonia and the Russian Federation, where over half of PWID in Kohtla-Järve (Estonia) and St. Petersburg (Russian Federation) were seropositive in 2012 (Table 1) (El-Bassel, Strathdee, \& Sadr, 2013; Jolley, et al., 2012; United Nations Joint Programme on HIV and AIDS, 2013; Uuskula, Raag, et al., 2015; Walsh \& Maher, 2013). Kohtla-Järve and St. Petersburg are situated on the Baltic Sea, on the northern part of two major heroin trafficking corridors linking Afghanistan to the heroin markets of Western Europe (United Nations Office on Drugs and Crime, 2012, 2015b). HIV epidemics in both cities have followed similar trajectories, driven by transmission among PWID but they differ on several contextual factors shown in Table 1.

Table 1. HIV epidemic, context and response in Kohtla-Järve (Estonia) and St. Petersburg (Russia)

\begin{tabular}{|c|c|c|c|}
\hline Indicator & All Estonia & Kohtla-Järve & St. Petersburg \\
\hline \multirow[t]{3}{*}{ HIV incidence (per 100 person years) } & $\begin{array}{l}20.7 \text { per } 100 \text { PY (2005) } \\
\text { (Uuskula, Des Jarlais, Raag, Pinkerton, \& Feelemyer, }\end{array}$ & 22 per 100 PY $(2012)^{(1)}$ & $\begin{array}{l}4.5 \text { per } 100 \text { PY (2009) (Andrei P. } \\
\text { Kozlov, et al., 2006) }\end{array}$ \\
\hline & 2015) & & \multirow{2}{*}{$\begin{array}{l}\text { 7.2/100 person-years (A. P. Kozlov, et } \\
\text { al., 2016) }\end{array}$} \\
\hline & 7.5 per 100 PY $(2011)^{(1)}$ & & \\
\hline HIV Prevalence & $\begin{array}{l}52 \% \text { (United Nations Joint Programme on HIV and } \\
\text { AIDS, 2013) }\end{array}$ & $\begin{array}{l}63 \% \text { (95\%Cl: } 56 \%-67 \%) \\
\text { (Uuskula, Raag, et al., 2015) }\end{array}$ & $\begin{array}{l}\text { 59\% (95\%Cl: 52\%-59\%) } \\
\text { (Uuskula, Raag, et al., 2015) }\end{array}$ \\
\hline PWID population size estimate & $\begin{array}{l}\text { 5,362 (range: 3,906-9,837) (Uuskula, } \\
\text { Rajaleid, Talu, Abel-ollo, \& Des Jarlais, 2013) }\end{array}$ & $x X$ & $\begin{array}{l}83,120(95 \% \mathrm{Cl}: 77,320-88,920) \\
\text { (Heimer \& White, 2010) }\end{array}$ \\
\hline \multirow[t]{2}{*}{$\%$ of population who inject drugs } & $\begin{array}{l}2.0 \% \text { (95\%Cl: } 1.4-5.0 \%) \text { (2008) } \\
\text { (Uuskula, et al., 2013) }\end{array}$ & \multirow[t]{2}{*}{$X X$} & \multirow[t]{2}{*}{ 5.5\% (2008) (Heimer \& White, 2010) } \\
\hline & $\begin{array}{l}0.9 \% \text { (95\%Cl: 0.7-1.7\%)(2009) } \\
\text { (Uuskula, et al., 2013) }\end{array}$ & & \\
\hline Needle/syringe services (start year) & 1997 & 2004 & NSPs not endorsed \\
\hline Needle/syringe services ( $n$, year) & $\begin{array}{l}22 \text { outreach, } 14 \text { fixed NSP (2014) } \\
\text { (National Institute for Health Development, 2015) }\end{array}$ & $x X$ & $X X$ \\
\hline Clean syringes per PWID per year & 125 syringes/PWID per year (2011) & $x X$ & $X X$ \\
\hline Services provided by & NGOs, government health services & NGOs & NGOs \\
\hline Drug substitution (start year) & 2001 & 2004 & OST illegal \\
\hline Type of drug treatment & Opiate substitution & Opiate substitution & Detoxification only ( 21 days) \\
\hline Coverage $(\%, \mathrm{n}$ and year $)$ & $15 \%$ of PWID $(n=919,2014)^{(3)}$ & $x X$ & $x x$ \\
\hline Services provided by & NGOs, clinics & NGOs, clinics & Centralized, in-patient \\
\hline
\end{tabular}

* Reference population for Estonia aged 15-44 years old; for St Petersburg aged 20-45 years old. HIV= Human Immune deficiency virus. PWID people who inject drugs. PY= person-years. NSP= Needle and Syringe Programme. NGO= Non-governmental organisation.

Notably, evidence-based harm reduction interventions including needle and syringe programmes (NSP) and opiate substitution treatment (OST) were introduced early in Kohtla-Järve (Estonia Ministry of Health, 2014; Mathers, et al., 2010), whereas in St Petersburg they are not endorsed by the government, OST remains illegal and clean 
needles and syringes are only provided by a few NGOs (Louisa Degenhardt, et al., 2014; European Monitoring Centre for Drugs and Addiction, 2015).

In both settings, most PWID injected heroin and synthetic opioids manufactured by illicit laboratories, namely fentanyls in Kohtla-Järve (introduced in Estonia following a heroin shortage in 2000) and methadone in St Petersburg (Eritsyan, et al., 2013; Grund, Zabransky, Irwin, \& Heimer, 2009; Heimer, Lyubimova, Barbour, \& Levina, 2015; Platt, et al., 2006). Estonia has reported one of the highest prevalence of amphetamine type stimulant (ATS) use in Europe (European Monitoring Centre for Drugs and Drug Addiction \& Europol, 2012; United Nations Office on Drugs and Crime, 2014) and data suggest that ATS has emerged as a major secondary drug among PWID in Kohtla-Järve and St. Petersburg (European Monitoring Centre for Drugs and Drug Addiction, 2010; Grund, et al., 2009; United Nations Office on Drugs and Crime, 2015a). However, it is not clear whether ATS injection has any relevance on risk behaviours and HIV epidemics in these settings.

ATS are psychostimulants that are relatively easy to synthesize and increasingly injected in settings previously dominated by opiates (Bao, et al., 2012; Booth, et al., 2008; Grund, et al., 2009; Hayashi, et al., 2011; Martin, et al., 2010). ATS have been associated with greater sexual risk, including multiple sex partners and unprotected sex, which may compound the risks of HIV acquisition among PWID (Baker, Kochan, Dixon, Wodak, \& Heather, 1994; Booth, et al., 2008; Shane Darke, Kaye, McKetin, \& Duflou, 2008; Gleghorn, Marx, Vittinghoff, \& Katz, 1998; Fred Molitor, et al., 1999; F. Molitor, Truax, Ruiz, \& Sun, 1998). ATS injection has been associated with more frequent injecting, needle/syringe sharing and HIV infection in settings where PWID also injected other drugs (Braine, Des Jarlais, Goldblatt, Zadoretzky, \& Turner, 2005; Crofts \& Aitken, 1997; Hayashi, et al., 2011; Andrei P. Kozlov, et al., 2006; TavitianExley, et al., 2017) but not when stimulants were reported as primary drug (Booth, et al., 2008; Kral, Bluthenthal, Booth, \& Watters, 1998; Swe \& Rashid, 2012; Talu, et al., 2010). Few studies have examined drug use patterns by main drug injected and their potential association with risk behaviours and HIV and HCV infection in Eastern European settings (Buster, et al., 2009; Folch, Merono, \& Casabona, 2006; Harrell, Mancha, Petras, Trenz, \& Latimer, 2012; Hayashi, et al., 2011; Hilary Klee, Faugier, Hayes, Boulton, \& Morris, 1990; Ross, Darke, \& Hall, 1997; Tavitian-Exley, Vickerman, Bastos, \& Boily, 2015) and the potential relevance of ATS injection in these epidemics remains unclear (European Monitoring Centre for Drugs and Drug Addiction, 
2010; European Monitoring Centre for Drugs and Drug Addiction \& Europol, 2011;

European Monitoring Centre for Drugs and Drug Addiction \& Škařupová, 2014).

Our aim is to assess whether primarily injecting ATS, as compared to opioids (heroin, synthetic heroin or methadone), is associated with increased injecting and sexual risk behaviours, and HIV status among PWID in Kohtla-Järve (Estonia) and St. Petersburg (Russian Federation), two East European locales with significant and epidemiologically similar HIV epidemics.

\section{METHODS}

\section{Study population}

Integrated biological and behavioural surveys (IBBS) of HIV prevalence were conducted among PWID in Kohtla-Järve between May and July 2012, and in St. Petersburg from November 2012 to June 2013. Both surveys have been reported on and described previously (Cepeda, et al., 2015; Dukhovlinova, et al., 2015; Heimer, et al., 2015; Tavitian-Exley, et al., 2017; Uuskula, Raag, et al., 2015) and used comparable recruitment criteria and respondent-driven sampling (RDS) survey methodology. Briefly, RDS starts with a diverse sample of seeds (6 seeds in Kohtla-Järve and 12 seeds in different districts of St. Petersburg, subsequently increased to 16 to cover key districts and compensate for unproductive seeds). Seeds were selected through needle/syringe programmes (NSP), to represent a range of demographic and drug profiles, and interviews and testing were conducted in fixed (Kohtla-Järve) and mobile clinics (St Petersburg). Each seed and subsequent participants was given an opportunity to recruit up to three PWID until a predetermined sample size was reached. Men and women aged 18 years or over, who had injected drugs in the past 30 days, lived in Kohtla-Järve or St. Petersburg and provided informed consent for the study were eligible. Eligibility was verified by the presence of injection marks and questions on injection practices before the start of the interview.

\section{Measures}

Information on demographic and social factors, injection and sexual risk behaviours, and access to harm reduction services were recorded by trained fieldworkers in a structured confidential interviewer-administered questionnaire, using standardised study items and questions from established survey instruments (e.g. WHO Drug Injecting 
study Phase II survey v2b) (Des Jarlais, Perlis, Stimson, Poznyak, \& Collab, 2006; Uuskula, Raag, et al., 2015).

\section{$H I V, H C V$ and $H S V$ status}

HIV sero-status was assessed using an HIV Antigen/Antibody Combo Assay (ADVIA Centaur, Siemens Healthcare Diagnostics) and HIV I/II Score line assay confirmatory test (INNO LIA, Fujirebio Europe) in Kohtla-Järve; rapid oral HIV testing was conducted in St. Petersburg using OraQuick ADVANCE® Rapid HIV-1/2 Antibody Tests (OraSure Technologies Inc.) and confirmed at the City AIDS Centre (Uuskula, Raag, et al., 2015). In Kohtla-Järve only, HCV and Herpes Virus Simplex (HSV) reactivity were measured using commercially available kits for antibodies to HCV (Murex anti-HCV v 4.0) and HSV-2 (HSV-2 IgG ELISA, IBL International GmbH).

The primary drug injected was categorised into mutually exclusive groups of primary ATS or primary opioid-injectors, based on the survey item main drug injected in the past 4 weeks. Injectors reporting no or "other" primary drug were compared with the rest of the sample and examined in descriptive analysis (and excluded in regression modelling).

\section{Demographic and contextual variables}

Demographic and contextual variables included age, sex, ethnicity, education completed (basic education/secondary and above), main source of income, living arrangements (stable/unstable), past month contact with an NSP, past year drug treatment (opioid substitution in Kohtla-Järve; any drug treatment in St. Petersburg) and having needles or syringes confiscated by the police.

\section{Injecting and sexual risk behaviours}

The behavioural variables examined included injecting-risk (using a 30 day recall period), sexual-risk behaviours (using a 6 month recall period) and serological markers for HIV (and in Kohtla-Järve only, HCV and HSV). Injecting behaviours of interest were past month injecting frequency ( $\geq$ daily injecting vs. <daily injecting), intensity of injection on the last day injected ( $\geq 2$ injections/day vs. $<2$ injections/day), injecting with used needles/syringes (sharing), sharing drug paraphernalia, back-loading (filling a syringe from a used syringe) and polydrug use (injecting a main drug and at least one other drug in the last month). Sexual risk behaviours included having a sex partner 
(regular or casual) who injected drugs, having been paid for sex (i.e. receiving money or drugs for sex ever), multiple sex partners ( $\geq 2$ sex partners in last 6 months) and consistent condom use (i.e. always) with sex partners. The variable "any sex in the last six months" was used to exclude non-sexually active PWID.

\section{Statistical analyses}

Descriptive statistics are presented for Kohtla-Järve and St. Petersburg separately (RDSadjusted estimates, using RDS-II sampling weights are presented in supplementary material) (Volz \& Heckathorn, 2008; Volz, et al., 2012; White, et al., 2015).

Two sets of logistic regressions were performed. The first set examined the determinants of ATS- and opioid-injection (dependent variable). In the second set, we assessed whether ATS (independent variable) was associated with a) injecting-risk behaviours, b) sexual-risk behaviours, and c) HIV, HCV and HSV prevalence. For both sets of regressions, we generated univariate and multivariable estimates (Kirkwood, 2003 ; UCLA Statistical Consulting Group, 2015). Results for the multivariable regressions were adjusted for age, sex, education, living arrangements, duration of injecting (and for contact with NSP and drug treatment in the second set of regressions). These variables were judged to be important potential confounders, based on published evidence and our conceptual framework (Supplementary material: Figure S.1) (Lemstra, Rogers, Thompson, Moraros, \& Buckingham, 2012; Marshall, et al., 2008; Marshall, et al., 2011; Poundstone, Strathdee, \& Celentano, 2004; Tavitian-Exley, 2016). Correlated variables were examined for collinearity and omitted from the model if variance attributed to collinearity (VIF) was $>2.5$ ). A complete case analysis was used and observations with missing values were omitted. Odds ratios (OR) with 95\% confidence intervals $(95 \% \mathrm{CI})$ were calculated while also adjusting for clustering of observations by recruitment seed (Kirkwood, 2003 ). Clusters were defined by a recruitment chain started by a given seed to account for the possibility that participants may be more likely to recruit other PWID with similar characteristics. This was achieved using the svy command in Stata (v.13.1) as in univariate analysis (Hosmer, 2000; Kirkwood, 2003 ; StataCorp., 2013; UCLA Statistical Consulting Group, 2015). Sampling weights were not taken into account in the regressions as their use is often unwarranted for causal inference (Solon, Haider, \& Wooldridge, 2013).

\section{Ethics}


Ethical approval was obtained from the Ethics Review Board of the University of Tartu (Estonia), the Institutional Review Board at NGO Stellit in St. Petersburg (Russian Federation), and the Human Investigation Committee at Yale University (USA).

\section{RESULTS}

\section{Characteristics of study sample}

Our study included 591 PWID in Kohtla-Järve and 811 in St. Petersburg (Table 2; supplementary material: Table S.1). In both cities, the majority of PWID were male, Russian-speaking or reporting stable living conditions (Table 2; Table S.1). However, more PWID in Kohtla-Järve were under the age of 30 and salaried or with a regular job than in St. Petersburg.

The primary drug commonly injected by PWID in both cities was a synthetic opioid (i.e. illicitly-manufactured fentanyl congeners in Kohtla-Järve; heroin and methadone produced in illicit laboratories in St. Petersburg) while ATS was the second most common drug class. Opioids were the primary drug for $61 \%$ of PWID in Kohtla-Järve and $96 \%$ in St. Petersburg; ATS was the main drug for 33\% in Kohtla-Järve and $4 \%$ in St. Petersburg (6\% of PWID in Kohtla-Järve had another or no primary drug).

More PWID had been in contact with a needle and syringe programme in the past six months in Kohtla-Järve (82\%) than in St. Petersburg (16\%) and over half had ever received some form of attention for substance use disorder (Table 2). Substitution treatment was reported by $13 \%$ of PWID in Kohtla-Järve and detoxification by $11 \%$ in St. Petersburg in the past 12 months. Similar proportions of PWID had needles/syringes confiscated by the police in the last six months in both cities but more PWID reported ever being incarcerated in Kohtla-Järve (55\%) than in St. Petersburg (34\%).

The majority of PWID in both cities had injected for more than 5 years with a mean age at first injection just under 19 years (Table S.1). Past-month injection risk behaviours were lower in Kohtla-Järve and up to nine times less frequent than in St. Petersburg. Past month polydrug use (injection of main and other drug) was equally widespread in both cities (47\% and 41\%). Fewer PWID in Kohtla-Järve had injected at least daily (24\%) than in St. Petersburg (36\%), shared needles and syringes (6\% and 58\%), filled from a used syringe (6\% and 53\%) or shared drug paraphernalia (7\% and 68\%).

Over three quarters of PWID in both cities had sexual intercourse in the last 6 months and over half had a sex partner who injected drugs (55\% in Kohtla-Järve and 58\% in St. 
Petersburg). Over a third of PWID had multiple sex partners (34\% and 49\%) and 7\% in Kohtla-Järve and 4\% in St. Petersburg, respectively, had ever been paid for sex. Close to half of PWID always used condoms with casual partners in Kohtla-Järve (58\%) and St. Petersburg (48\%). Due to the high non-response rate $(>50 \%)$ for some sexual risk behaviours in Kohtla-Järve, results for this city were not shown given the high likelihood of bias; we only analysed the effect of ATS- or opioid-injection for those variables in St. Petersburg (Table S.1). More than half of PWID tested positive for HIV in Kohtla-Järve (61\%) and in St. Petersburg (56\%). HCV and HSV reactivity, measured in Kohtla-Järve only, was $75 \%$ and $32 \%$, respectively.

\section{Associations between primary ATS injection and injecting and sexual risk behaviours and serology in Kohtla-Järve}

Determinants of ATS injection

Determinants of primary ATS injection are presented in Table 3. In Kohtla-Järve, ATS injectors were younger than opioid injectors with greater odds of being under 30 years of age (adjusted Odds Ratio $(\mathrm{aOR})=2.1 ; 95 \% \mathrm{CI}: 1.4-3.2)$ and of later initiation to injection (aOR: 1.1; 95\%CI: 1.0-1.4) than their opioid-injecting peers. The groups did not differ on other demographic characteristics. ATS injectors had lower odds of pastyear drug treatment ( $\mathrm{aOR}=0.5 ; 95 \% \mathrm{CI}$ : 0.3-0.9), past-month contact with an NSP $(\mathrm{aOR}=0.2 ; 95 \% \mathrm{CI}: 0.2-0.6)$, having needles/syringes confiscated by the police $(\mathrm{aOR}=0.3 ; 95 \% \mathrm{CI}: 0.1-0.8)$ and incarceration ( $\mathrm{aOR}=0.3 ; 95 \% \mathrm{CI}: 0.2-0.5)$. They had higher odds of obtaining clean needles/syringes from a pharmacy than an NSP (aOR: 4.9 (95\%CI: 3.5-6.9).

\section{Associations with injecting risk behaviours}

Primary ATS injection was associated with a number of injecting risk behaviours (Table 4). ATS injectors were more likely to have injected for less than 5 years (aOR=3.5; 95\% CI: 1.9-6.2) (Table 4). ATS injection was negatively associated with frequent injecting $(\mathrm{aOR}=0.3$; 95\%CI: 0.2-0.6), lifetime needle/syringe-sharing $(\mathrm{aOR}=0.3 ; 95 \% \mathrm{CI}$ : 0.2 $0.5)$ and back-loading ( $\mathrm{aOR}=0.4 ; 95 \% \mathrm{CI}$ : 0.2-0.8) and positively associated with polydrug use $(\mathrm{aOR}=2.0 ; 95 \% \mathrm{CI}: 1.1-3.5)$. Past month unsafe sharing practices such as sharing needles/syringe and drug paraphernalia were generally lower among primary ATS injectors but did not reach statistical significance (Table 4). 
One third of PWID reported multiple sex partners with no significant difference between primary ATS- and opioid-injectors; however ATS injectors had greater odds of ever being paid for sex $(\mathrm{aOR}=2.6$; 95\%CI: 1.2-5.7)(Table 5).

Associations with HIV, HCV and HSV prevalence

Primary ATS injectors in Kohtla-Järve had lower odds of testing positive for HIV $(\mathrm{aOR}=0.6$; 95\%CI: 0.5-0.8) and having antibodies to hepatitis $\mathrm{C}(\mathrm{aOR}=0.5$; 95\%CI: 0.3 0.6) in multivariate analysis, compared to primary opioid injectors (Table 6). HSV-2 antibody status was not associated with ATS injection.

\section{Associations between primary ATS injection and injecting and sexual risk behaviours and HIV in St. Petersburg}

Determinants of ATS injection

In St. Petersburg, primary ATS injectors had higher odds of being under 30 years of age $(\mathrm{aOR}=6.8 ; 95 \% \mathrm{CI}: 2.8-16.5)$, female $(\mathrm{aOR}=1.7$; 95\%CI: 0.7-4.1), later initiation to injection (aOR: 1.3; 95\%CI: 1.1-1.4) or having unstable living arrangements (aOR=2.2; 95\%CI: 1.0-4.6) than opioid injectors (Table 3). Contact with NSP and drug treatment were very low in St. Petersburg and did not differ between ATS- and opioid-injectors. However ATS injectors had greater odds of obtaining needles and syringes from sources other than an NSP (e.g. from friends, other PWID, a drug dealer or in the street) $(\mathrm{aOR}=35 ; 95 \% \mathrm{CI}: 2.7-472)$ and lower odds of having been incarcerated and having needles/syringes confiscated compared to opioid injectors.

\section{Associations with injecting risk behaviours}

Primary ATS injectors were more likely to report fewer than 5 years of injecting $(\mathrm{aOR}=8.3$; 95\%CI: 2.2-31.6)(Table 4). Several injecting risk behaviours were negatively associated with ATS injection. Primary ATS injectors had lower odds of daily or more frequent injecting ( $\mathrm{aOR}=0.2$; 95\%CI: 0.1-0.9), injecting more than twice a day (aOR: 0.3 ; 95\%CI: 0.1-0.6), sharing needles and syringes ( $\mathrm{aOR}=0.2 ; 95 \% \mathrm{CI}: 0.1-0.6$ ), filling a syringe from a used syringe $(\mathrm{aOR}=0.2 ; 95 \% \mathrm{CI}: 0.1-0.5)$ and sharing drug paraphernalia (aOR=0.3; 95\%CI: 0.1-0.6) than opioid injectors. Polydrug use was frequent among both ATS- and opioid-injectors but did not differ significantly between the two groups. 
Almost half of PWID in the Russian city reported multiple sex partners, with no significant difference between ATS- and opioid-injectors (Table 5). In multivariate analysis, ATS injectors had greater odds of being paid for sex $(\mathrm{aOR}=5.2$; 95\%CI: 1.027.0) and using condoms consistently with casual sex partners ( $\mathrm{aOR}=8.0$; 95\%CI: 1.1 $60.0)$.

\section{Associations with HIV prevalence}

Primary ATS injectors in St. Petersburg had lower odds of testing positive for HIV than PWID injecting opioid (aOR=0.3; 95\%CI: 0.1-0.7)(Table 6). HCV and HSV serology were not collected in St. Petersburg.

\section{DISCUSSION}

We compared risk behaviours and HIV status among self-identified primary ATSinjectors and opioid-injectors in two settings with severe epidemics of drug use and HIV. Our results suggest that, in both locations, PWID primarily injecting ATS consistently differed on demographic characteristics and reported less or equally risky injecting behaviours compared to those who mainly injected opioids. ATS injectors in both cities were younger but started injecting later than opiate injectors, were more likely to report less than 5 years' injecting and generally at earlier stages in their drug injecting careers. The younger age and later onset of injecting among ATS injectors, suggested the emergence of a different group of PWID who may be at earlier stages of drug dependence and injected less frequently than their opioid-injecting peers.

In St. Petersburg, contact with NSPs was generally low and did not differ between the two groups; there primary ATS injectors were less likely to have injected with used needles/syringes, shared drug paraphernalia or back-loaded than opiate injectors. However in Kohtla-Järve, where harm reduction services are established, ATS injectors were significantly less likely than opiate injectors to have had contact with NSPs and reported similar prevalence of sharing needles/syringes or drug paraphernalia but were less likely to back-load than opiate injectors. Although the cross-sectional nature of our study precludes attributing causality, it is possible that harm reduction services in Kohtla-Järve (including OST) contributed to reducing injecting risk behaviours among opiate injectors thus "levelling" injecting risk between the two groups in this city.

Our findings are generally consistent with those of studies, where self-reported primary ATS injection was associated with younger age and fewer years of injecting among 
PWID in Australia, the USA, Ukraine and elsewhere in Estonia (Booth, et al., 2008;

Braine, et al., 2005; Fairbairn, et al., 2007; Kaye \& Darke, 2000; Talu, et al., 2010) and where primary ATS injectors reported similar or lower frequency of injection (Booth, et al., 2008; Braine, et al., 2005; Shane Darke, et al., 2008; Gleghorn, et al., 1998; Kaye \& Darke, 2000; Maher, et al., 2007; Talu, et al., 2010) and similar frequency of needle and syringe-sharing than opiate injectors (Gleghorn, et al., 1998; Kaye \& Darke, 2000; Talu, et al., 2010). However the lower or equal injecting risk behaviours reported by primary ATS injectors in our study contrast with findings from studies where ATS injection was reported but not as primary drug and occurred in the presence of other injection drugs such as heroin (Braine, et al., 2005; Crofts \& Aitken, 1997; Hayashi, et al., 2011; Andrei P. Kozlov, et al., 2006; Tavitian-Exley, et al., 2017).

Both ATS-injectors and opioid-injectors in this study reported similarly high prevalence of sexual risk, including multiple sex partners, however primary ATS injectors were more likely to have ever been paid for sex. ATS can be used to increase energy, stamina, libido and reduce social and sexual inhibition and injection often occurs with peers or sexual partners, possibly generating more needle-sharing opportunities ( $\mathrm{S}$. Darke, Ross, Cohen, Hando, \& Hall, 1995; H. Klee, 1993). Several other studies of PWID also found positive associations between ATS injection and multiple sex partners, unprotected sex and trading sex for money or drugs (Lorvick, Martinez, Gee, \& Kral, 2006; Fred Molitor, et al., 1999).

The frequency of sexual risk in both cities and possible intersection with sex work highlight the potential for sexual transmission of HIV, and an unmet need to engage diverse PWID sub-groups with prevention and risk reduction messages emphasising sexual as well injecting risks (Lorvick, et al., 2006; F. Molitor, et al., 1998; Rondinelli, et al., 2009). The prevalence of polydrug use was similarly high in both groups and cities, and associated with ATS injection in Kohtla-Järve.

Finally, HIV prevalence and HCV in Kohtla-Järve, were lower among ATS- than opioid-injectors, consistent with their shorter, cumulative exposure to risk, resulting from younger age and later onset of injecting (Andrei P. Kozlov, et al., 2006; Martin, et al., 2010). These differences in HIV status remained after adjusting for factors such as injecting duration, suggesting that other determinants also play a role. Primary ATS injectors are nevertheless vulnerable to HIV acquisition as a result of their age (and 
gender in St. Petersburg), high prevalence of sexual risk behaviours and low contact with harm reduction services (i.e. NSP and drug substitution treatment in Kohtla-Järve). The propensity of ATS injectors in Kohtla-Järve to obtain clean needles and syringes from pharmacies rather than NSPs when the majority of PWID in the sample were in contact with harm reduction services, also suggests they were not being reached (Vorobjov, et al., 2009). Furthermore, the lower odds of substitution treatment among ATS injectors in Kohtla-Järve, may be explained by the provision of methadone, intended for opioid (and not ATS) use disorders. Opioid-based substitution treatment has shown to reduce injecting behaviours and HIV infection among opioid users, and supports adherence to highly active anti-retroviral therapy (HAART) but no proven pharmacological treatment exists yet for ATS injectors (Ahamad, et al., 2015; MacArthur, et al., 2012; World Health Organization, 2013). Still, where ATS use is prevalent, services that are tailored to the different demographic characteristics and needs of ATS injectors, and include psychosocial interventions, need to be integrated to harm reduction programmes (Mehrjerdi, Abarashi, Noroozi, Arshad, \& Zarghami, 2014; United Nations Office on Drugs and Crime, 2010). The problem of ATS injection in these cities, and globally, requires effective low-threshold services able to engage injectors who, are young and/or female, do not fit "conventional" drug use profiles associated with heroin and neither seek nor desire contact with services focused primarily on opioid injectors (Lorvick, et al., 2006; Pates, 2013; Shearer, Sherman, Wodak, \& Van Beek, 2002; Vorobjov, et al., 2009).

Moreover, while few studies have looked at the life course of drug use among primary ATS injectors, especially in resource-limited settings (Brecht, Huang, Evans, \& Hser, 2008), longitudinal and qualitative research would help to understand how primary ATS-injection and associated behavioural risks evolve over time. Consistent and systematic drug monitoring would also contribute to better understanding heterogeneity among PWID.

Several limitations need to be acknowledged. First, our findings may only be generalizable to other PWID populations in Estonia or the Russian Federation. Second, obtaining standard probability samples of PWID populations is challenging due to the hidden nature of this group, their stigmatised behaviours and the absence of a sampling frame. Although RDS surveys have demonstrated the ability to reach such hidden population sub-groups, the representativeness of our samples cannot be verified (Abdul- 
Quader, et al., 2006; Heckathorn, 1997; Lisa G Johnston \& Sabin, 2010). Third, information on injecting and sexual risk behaviours was collected through self-reports and social desirability bias may affect the results. Self-reporting using intervieweradministered questionnaires has shown reliability in several studies and a 30-day period, as was used in this study, has shown to produce reliable recall on drug use and injecting behaviours among PWID (Shane Darke, 1998; Des Jarlais, et al., 1999; Napper, Fisher, Reynolds, \& Johnson, 2010). Additionally, the small number of ATS injectors in St. Petersburg and wide confidence intervals limited analyses for this city. Finally, given the high prevalence of polydrug use in this population, dynamic nature of drug use and shorter recall, it is also conceivable that misclassification may have occurred between ATS-and opioid-injectors thus leading to possible bias. However, non-differential misclassification of the exposure generally biased the inferences towards the null and if this is the case, our results could be considered conservative (Dosemeci, Wacholder, \& Lubin, 1990; Kirkwood, 2003 ).

The strengths of this study include its large sample size and comparison in two Eastern European locations reporting a high prevalence of HIV and injection of different drug classes. Recruitment of two large and diverse PWID samples was facilitated by the use of RDS and reported according to the STROBE-RDS statement (L. G. Johnston, et al., 2016; White, et al., 2015). We systematically compared self-identified PWID injecting different drug classes, using consistent definitions, study methods and tested tools, and highlighted important differences, consistent across sites, between primary ATS- and opioid-injectors, of relevance to policy and programmes.

Primary ATS injectors reported lower or similar injecting risk behaviours, lower HIV prevalence than opioid injectors and engaged less with services. Both groups had high levels of multiple sex partners but primary ATS injection was associated with paid sex, suggesting overlaps between injecting and sexual risk. Low threshold services with interventions (e.g. behavioural) targeting the needs of young stimulant injectors are needed to increase their contact with services and reduce sexual risk behaviours. The coverage of harm reduction services, including sexual risk reduction, needs to be increased significantly in St. Petersburg for all PWID. 


\section{Acknowledgments}

We are grateful to field staff and peers who conducted the surveys and interviews, to harm reduction programmes ('Me aitamesind" in Kohtla-Järve and 'Diakonia' in St. Petersburg) and staff who assisted with the identification of seeds and provided facilities for interviewing and serological testing, to NGO "Stellit" for contributing to the survey methodology and to participants for their time.

\section{Author contributions}

ITE, MC and MMG developed the study design, ITE conducted the statistical analyses and drafted the manuscript with MMG, MC and LP. RH, OL and AU designed the surveys in St. Petersburg and Kohtla-Järve, led the surveys, data collection and provided critical review in the interpretation of results and manuscript. All authors reviewed the manuscript.

Declaration of interest: none declared

\section{Removed from the introduction}

[Remove >] An estimated 970,000 of the 3.1 million PWID in this region are infected with HIV (Jolley, et al., 2012; Mathers, et al., 2008; United Nations Joint Programme on HIV and AIDS, 2013, 2014).

[Removed] ATS were estimated to contribute two thirds of the global burden of stimulant dependence in 2010 and ATS use has increased in Eastern Europe, Central and Southeast Asia (L. Degenhardt, et al., 2014; Mehrjerdi, 2013; Mehrjerdi, et al., 2014; Saw, et al., 2014; United Nations Office on Drugs and Crime, 2015a, 2016).

\section{Removed from the discussion}

Nevertheless, ATS may provide an entry point for young injectors who experiment with stimulant drugs and move on to inject other addictive substances (Van Ameijden, Van den Hoek, Hartgers, \& Coutinho, 1994). 
Table 2. Characteristics of sample and by reported primary amphetamine injection in Kohtla-Järve (Estonia) and St. Petersburg (Russian Federation)

\begin{tabular}{|c|c|c|c|c|c|c|c|c|}
\hline \multirow[b]{2}{*}{$\begin{array}{l}\text { CHARACTERISTICS } \\
\text { DEMOGRAPHIC VARIABLES }\end{array}$} & \multicolumn{4}{|c|}{ Kohtla-Järve } & \multicolumn{4}{|c|}{ St. Petersburg } \\
\hline & $\begin{array}{c}\text { All(1) PWID } \\
\text { Kohtla-Järve }\end{array}$ & $\begin{array}{c}N \\
591\end{array}$ & $\begin{array}{c}\text { Primary } \\
\text { amphetamine } \\
(\%)^{(1)}\end{array}$ & $\begin{array}{c}n \\
195\end{array}$ & $\begin{array}{c}\text { All(1) PWID } \\
\text { St. Petersburg }\end{array}$ & $\begin{array}{c}N \\
811\end{array}$ & $\begin{array}{c}\text { Primary } \\
\text { amphetamine } \\
(\%)^{(1)}\end{array}$ & $\begin{array}{c}n \\
27\end{array}$ \\
\hline \multicolumn{9}{|l|}{ Sex } \\
\hline Female & $26 \%$ & 155 & $29.7 \%$ & 58 & $22 \%$ & 180 & $48.2 \%$ & 13 \\
\hline Male & $74 \%$ & 434 & $70.3 \%$ & 137 & $78 \%$ & 631 & $51.9 \%$ & 14 \\
\hline Missing & & 2 & & 0 & & 0 & & 0 \\
\hline \multicolumn{9}{|l|}{ Age group } \\
\hline$<30$ years & $50 \%$ & 294 & $61.5 \% *$ & 120 & $30 \%$ & 241 & $74.1 \% *$ & 20 \\
\hline$>=30$ years & $50 \%$ & 297 & $38.5 \%$ & 75 & $70 \%$ & 570 & $25.9 \%$ & 7 \\
\hline Missing & & 0 & & 0 & & 0 & & 0 \\
\hline \multicolumn{9}{|l|}{ Ethnicity } \\
\hline Estonian & $12 \%$ & 66 & $12.3 \%$ & 24 & $0 \%$ & 0 & $0 \%$ & 0 \\
\hline Other & $7 \%$ & 43 & $5.1 \%$ & 10 & $4 \%$ & 36 & $3.7 \%$ & 1 \\
\hline Russian & $81 \%$ & 481 & $82.6 \%$ & 161 & $96 \%$ & 775 & $96.3 \%$ & 26 \\
\hline Missing & & 1 & & 0 & & 0 & & 0 \\
\hline \multicolumn{9}{|l|}{ Education completed } \\
\hline Basic $\left(9^{\text {th }}\right.$ grade)/vocational & $80 \%$ & 472 & $81.0 \%$ & 158 & $58 \%$ & 475 & $29.6 \% *$ & 8 \\
\hline Secondary $\left(11^{\text {th }}\right.$ grade $)$ & $19 \%$ & 116 & $19.0 \%$ & 37 & $30 \%$ & 243 & $51.9 \%$ & 14 \\
\hline Higher (SP only) & $1 \%$ & 3 & $0 \%$ & 0 & $12 \%$ & 93 & $18.5 \%$ & 5 \\
\hline Missing & & 0 & & 0 & & 0 & & 0 \\
\hline \multicolumn{9}{|l|}{ Living arrangements } \\
\hline Unstable (hostel, dormitory, shelter) & $40 \%$ & 238 & $39.5 \%$ & 77 & $36 \%$ & 292 & $51.9 \% *$ & 14 \\
\hline Stable (own or partner's flat/house) & $60 \%$ & 352 & $60.5 \%$ & 118 & $64 \%$ & 519 & $48.2 \%$ & 13 \\
\hline Missing & & 1 & & 0 & & 0 & & 0 \\
\hline \multicolumn{9}{|l|}{ Main income source } \\
\hline irregular/illicit (SP only) & $3 \%$ & 15 & - & - & $16 \%$ & 134 & $3.7 \%$ & 1 \\
\hline non-regular/dependant & $33 \%$ & 193 & $38.5 \%$ & 74 & $39 \%$ & 312 & $37.0 \%$ & 10 \\
\hline regular/salaried & $64 \%$ & 375 & $61.5 \%$ & 118 & $45 \%$ & 362 & $59.3 \%$ & 16 \\
\hline Missing & & 8 & & 3 & & 3 & & 0 \\
\hline \multicolumn{9}{|l|}{ CONTEXTUAL VARIABLES } \\
\hline \multicolumn{9}{|l|}{ Lifetime drug treatment } \\
\hline Ever had drug treatment & $55 \%$ & 324 & $32.8 \% *$ & 64 & $72 \%$ & 582 & $25.9 \% *$ & 7 \\
\hline Never in treatment & $45 \%$ & 267 & $67.2 \%$ & 131 & $28 \%$ & 229 & $74.1 \%$ & 20 \\
\hline Missing & & 0 & & 0 & & 0 & & 0 \\
\hline \multicolumn{9}{|l|}{ Drug/substitution treatment } \\
\hline Yes (12 months) & $13 \%$ & 75 & $6.7 \% *$ & 13 & $11 \%$ & 86 & $14.8 \%$ & 4 \\
\hline No & $87 \%$ & 516 & $93.3 \%$ & 182 & $89 \%$ & 724 & $85.2 \%$ & 23 \\
\hline Missing & & 0 & & 0 & & 1 & & 0 \\
\hline \multicolumn{9}{|l|}{ NSP programme (4 weeks) } \\
\hline Contact with NSP & $82 \%$ & 451 & $66.7 \% *$ & 124 & $16 \%$ & 119 & $3.7 \% *$ & 1 \\
\hline No contact with NSP & $18 \%$ & 102 & $33.3 \%$ & 62 & $84 \%$ & 645 & $96.3 \%$ & 26 \\
\hline Missing & & 38 & & 9 & & 47 & & 0 \\
\hline \multicolumn{9}{|l|}{ Source of clean needle/syringes } \\
\hline Other (friend, dealer, street) & $5 \%$ & 27 & $66.7 \% *$ & 124 & $4 \%$ & 30 & $40.7 \% *$ & 11 \\
\hline Pharmacist/chemist & $13 \%$ & 75 & $26.3 \%$ & 49 & $81 \%$ & 615 & $55.6 \%$ & 15 \\
\hline NSP & $82 \%$ & 451 & $7.0 \%$ & 13 & $16 \%$ & 119 & $3.7 \%$ & 1 \\
\hline Missing & & 38 & & 9 & & 47 & & 0 \\
\hline \multicolumn{9}{|l|}{ Incarceration } \\
\hline Ever in prison & $55 \%$ & 324 & $30.3 \% *$ & 59 & $34 \%$ & 274 & $7.4 \% *$ & 2 \\
\hline Never in prison & $45 \%$ & 267 & $69.7 \%$ & 136 & $66 \%$ & 537 & $92.6 \%$ & 25 \\
\hline Missing & & 0 & & 0 & & 0 & & 0 \\
\hline \multicolumn{9}{|l|}{ Needles/syringes confiscated } \\
\hline Had N/S confiscated & $31 \%$ & 404 & $15.9 \% *$ & 31 & $26 \%$ & 212 & $0 \%$ & 0 \\
\hline No N/S confiscated & $69 \%$ & 184 & $84.1 \%$ & 164 & $74 \%$ & 599 & $100 \%$ & 27 \\
\hline Missing & & 3 & & 0 & & 0 & & 0 \\
\hline
\end{tabular}

Table 1: (1) Column percentage. Crude estimates are presented for Kohtla-Järve and St. Petersburg; adjusted estimates using respondent driven sampling weights (RDS-II, Volz-Heckathorn) are shown in supplementary material as is the number of missing observations. NSP=Needle and syringe programme. HIV= Human Immune deficiency Virus. (2) Drug/substitution treatment in last 12 months refers to opiate drug substitution (OST) in Kohtla-Järve and to detoxification (non-OST) in St Petersburg. *Statistically significant result in comparisons of ATS- and opioid-injectors using Pearson's Chi-squared test for proportions ( $p$-value $<0.05$ ) or Fisher's exact when expected cell count is $<4$. 
Table 3. Predictors of primary ATS injection in Kohtla-Järve (Estonia) and St. Petersburg (Russian Federation)

\begin{tabular}{|c|c|c|c|c|}
\hline \multirow{2}{*}{$\begin{array}{l}\text { DEMOGRAPHIC CHARACTERISTICS } \\
\text { (reference: opioid injectors) }\end{array}$} & \multicolumn{2}{|c|}{ Kohtla-Järve - ATS injectors ( $n=195)$} & \multicolumn{2}{|c|}{ St. Petersburg - ATS injectors $(n=27)$} \\
\hline & $\mathrm{OR}^{(1)} 95 \% \mathrm{Cl}$ & $\mathrm{aOR}^{(2)} 95 \% \mathrm{Cl}$ & $\mathrm{OR}^{(1)} 95 \% \mathrm{Cl}$ & $\mathrm{aOR}^{(2)} 95 \% \mathrm{Cl}$ \\
\hline \multicolumn{5}{|l|}{ Sex } \\
\hline Female & $1.3(0.9-1.9)$ & $1.3(0.9-1.6)$ & $3.4(1.0-11.5)$ & $1.7(0.7-4.1)$ \\
\hline Male & $r e f$ & $r e f$ & $r e f$ & ref \\
\hline \multicolumn{5}{|l|}{ Age group } \\
\hline$<30$ years & $2.0(1.3-3.3)$ & $2.1(1.4-3.2)$ & $7.3(2.6-20.3)$ & $6.8(2.8-16.5)$ \\
\hline$>=30$ years & ref & ref & ref & ref \\
\hline \multicolumn{5}{|l|}{ Ethnicity } \\
\hline Estonian & $1.2(0.8-1.9)$ & $1.1(0.6-2.1)$ & - & - \\
\hline Other & $0.6(0.2-1.8)$ & $0.6(0.3-1.1)$ & $0.8(0.1-9.2)$ & $0.8(0.1-11.4)$ \\
\hline Russian & ref & & ref. & ref. \\
\hline \multicolumn{5}{|l|}{ Education completed } \\
\hline Basic (9th grade)/vocational & $1.1(0.6-1.8)$ & $1.0(0.6-1.7)$ & $0.3(0.05-1.7)$ & $2.6(1.2-6.7)$ \\
\hline 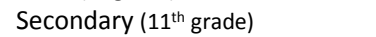 & ref & ref & $1.1(0.4-3.2)$ & $2.5(0.7-9.6)$ \\
\hline Higher (SP only) & - & - & ref & $r e f$ \\
\hline \multicolumn{5}{|l|}{ Living arrangements } \\
\hline Unstable (hostel, dorm, shelter) & $0.9(0.6-1.4)$ & $0.9(0.6-1.2)$ & $2.0(0.9-4.1)$ & $2.2(1.0-4.6)$ \\
\hline Stable (own/partner home) & ref & ref & ref & ref \\
\hline \multicolumn{5}{|l|}{ Main income source } \\
\hline irregular/illicit (SP only) & - & - & $0.2(0.02-1.6)$ & $0.1(0.05-1.5)$ \\
\hline non-regular/dependant & $1.3(0.9-1.7)$ & $1.0(0.6-1.5)$ & $0.7(0.4-1.5)$ & $0.8(0.4-1.5)$ \\
\hline regular/salaried & ref. & ref. & ref & ref \\
\hline \multicolumn{5}{|l|}{ Age at first injection } \\
\hline Primary ATS/Opioid & $1.1(1.1-1.2)$ & $1.1(1.0-1.2)$ & $1.1(1.0-1.3)$ & $1.3(1.1-1.4)$ \\
\hline \multicolumn{5}{|l|}{ CONTEXTUAL VARIABLES } \\
\hline \multicolumn{5}{|l|}{ Lifetime drug treatment } \\
\hline Ever drug treatment & $0.2(0.2-0.3)$ & $0.3(0.2-0.5)$ & $0.2(0.1-0.6)$ & $0.2(0.1-0.5)$ \\
\hline Never in treatment & ref & ref & ref & ref \\
\hline \multicolumn{5}{|l|}{ Drug/substitution treatment } \\
\hline Yes (12 months) & $0.4(0.2-0.7)$ & $0.5(0.3-0.9)$ & $1.5(0.4-5.8)$ & $1.9(0.3-12.7)$ \\
\hline No & ref. & ref & ref & ref \\
\hline \multicolumn{5}{|l|}{ NSP programme (4 weeks) } \\
\hline Contact with NSP & $0.2(0.1-0.3)$ & $0.2(0.2-0.6)$ & $0.2(0.05-1.0)$ & $0.4(0.1-2.2)$ \\
\hline No contact with NSP & ref & $r e f$ & ref & ref \\
\hline \multicolumn{5}{|l|}{ Source of clean needle/syringes } \\
\hline Other (friend, dealer, street) & $2.4(0.7-9.9)$ & $2.0(0.5-7.9)$ & $67(8.1-544)$ & 35 (2.7-472) \\
\hline Pharmacist/chemist & $6.0(4.1-8.6)$ & $4.9(3.5-6.9)$ & $2.9(0.6-14.2)$ & $1.8(0.3-9.3)$ \\
\hline NSP & ref & ref & ref & ref \\
\hline \multicolumn{5}{|l|}{ Incarceration } \\
\hline Ever in prison & $0.2(0.1-0.3)$ & $0.3(0.2-0.5)$ & $0.2(0.1-0.3)$ & $0.2(0.1-0.8)$ \\
\hline Never in prison & ref & ref & ref & ref \\
\hline \multicolumn{5}{|l|}{ Needles/syringes confiscated } \\
\hline Had N/S confiscated & $0.3(0.1-0.9)$ & $0.3(0.1-0.8)$ & - & Too few obs. \\
\hline No N/S confiscated & ref & ref & & \\
\hline
\end{tabular}

Table 2. (1) Odds ratio (OR) with $95 \%$ confidence intervals $(95 \% \mathrm{Cl})$ refer to primary Amphetamine-Type Stimulant (ATS) versus opioids (reference group is "primary opioid injectors"). (2) Multivariable model for ATS was adjusted for predictors: age, sex, education, duration of injecting (and living arrangements in St. Petersburg). Statistically significant results at the $\alpha<0.05$ are marked in bold. (3) Needle/syringe programme (NSP), drug treatment and needles/syringes confiscated were adjusted for in models where the outcome was injecting risk. (4) Drug/substitution treatment in last 12 months refers to opiate drug substitution (OST) in Kohtla-Järve and to detoxification (non-OST) in St Petersburg. 
Table 4. Association between ATS injection and injecting risk behaviours (Kohtla-Järve, St. Petersburg)

\begin{tabular}{|c|c|c|c|c|}
\hline \multirow{2}{*}{$\begin{array}{l}\text { OUTCOMES: INJECTING RISK }{ }^{(3)} \\
\text { (reference: opioid injectors) }\end{array}$} & \multicolumn{2}{|c|}{ Kohtla-Järve - ATS injectors ( $n=195)$} & \multicolumn{2}{|c|}{ St. Petersburg - ATS injectors $(n=27)$} \\
\hline & $\mathrm{OR}^{(1)} 95 \% \mathrm{Cl}$ & $\mathrm{aOR}^{(2)} 95 \% \mathrm{Cl}$ & $\mathrm{OR}^{(1)} 95 \% \mathrm{Cl}$ & $\mathrm{aOR}^{(2)} 95 \% \mathrm{Cl}$ \\
\hline \multicolumn{5}{|l|}{ Duration of injecting } \\
\hline$\leq 5$ years & $6.1(3.8-9.6)$ & $3.5(1.9-6.2)$ & $14.7(4.2-51)$ & $8.3(2.2-31.6)$ \\
\hline$>5$ years & ref. & ref & ref. & ref \\
\hline \multicolumn{5}{|l|}{ Frequency of injecting } \\
\hline Daily or more & $0.2(0.1-0.5)$ & $0.3(0.2-0.6)$ & $0.2(0.1-1.0)$ & $0.2(0.1-0.9)$ \\
\hline Less than daily & ref. & ref. & ref. & ref. \\
\hline \multicolumn{5}{|l|}{ Ever shared needles/syringes } \\
\hline Yes & $0.2(0.1-0.3)$ & $0.3(0.2-0.5)$ & $0.05(0.03-0.1)$ & $0.1(0.1-0.2)$ \\
\hline No & ref. & ref. & ref. & ref. \\
\hline \multicolumn{5}{|c|}{ Injected w/used needles/syringes } \\
\hline Yes & $0.5(0.1-1.6)$ & $0.5(0.2-1.5)$ & $0.1(0.05-0.3)$ & $0.2(0.1-0.6)$ \\
\hline No & ref. & ref. & ref. & ref. \\
\hline \multicolumn{5}{|c|}{ Filled from working syringe (back-loaded) } \\
\hline Yes & $0.4(0.2-1.2)$ & $0.4(0.2-0.8)$ & $0.1(0.1-0.3)$ & $0.2(0.1-0.5)$ \\
\hline No & ref. & ref. & ref. & ref. \\
\hline \multicolumn{5}{|l|}{ Shared drug paraphernalia } \\
\hline Yes & $0.5(0.2-1.3)$ & $0.5(0.3-1.2)$ & $0.2(0.1-0.3)$ & $0.3(0.1-0.6)$ \\
\hline No & ref. & ref. & ref. & ref. \\
\hline \multicolumn{5}{|l|}{ Any polydrug use (any) } \\
\hline$\geq 2$ drugs & $2.2(1.5-3.4)$ & $2.0(1.1-3.5)$ & $0.7(0.4-1.2)$ & $0.7(0.4-1.2)$ \\
\hline Main drug only & ref. & ref. & ref. & ref. \\
\hline
\end{tabular}

Table 3. (1) Odds ratio (OR) with $95 \%$ confidence intervals (95\% Cl) refer to primary Amphetamine-Type Stimulant (ATS) versus opioids (reference group). (2) Multivariable models were adjusted for age, sex, education, duration of injecting, needle/syringe programme (NSP), drug/substitution treatment, needles/syringes (N/S) confiscated (and living arrangements in St. Petersburg). Statistically significant results at the $\alpha<0.05$ are marked in bold. (3) Injecting risk in the last 4 weeks.

Table 5. Associations between ATS injection and sexual risk behaviours (Kohtla-Järve, St. Petersburg)

\begin{tabular}{|c|c|c|c|c|}
\hline \multirow{2}{*}{$\begin{array}{l}\text { OUTCOMES: SEXUAL RISK }{ }^{(3)} \\
\text { (reference: opioid injectors) }\end{array}$} & \multicolumn{2}{|c|}{ Kohtla-Järve - ATS injectors ( $n=195)$} & \multicolumn{2}{|c|}{ St. Petersburg - ATS injectors ( $n=27)$} \\
\hline & $\mathrm{OR}^{(1)} 95 \% \mathrm{Cl}$ & $\mathrm{aOR}^{(2)} 95 \% \mathrm{Cl}$ & $\mathrm{OR}^{(1)} 95 \% \mathrm{Cl}$ & $\mathrm{aOR}^{(2)} 95 \% \mathrm{Cl}$ \\
\hline \multicolumn{5}{|l|}{ Any sex in 6 months } \\
\hline Yes & $1.8(1.0-3.3)$ & $1.7(0.9-3.3)$ & $1.8(0.8-3.9)$ & $1.6(0.7-3.8)$ \\
\hline No & ref. & ref & ref. & ref \\
\hline \multicolumn{5}{|l|}{ Regular sex partner injects } \\
\hline Yes & $0.7(0.4-1.1)$ & $0.8(0.5-1.9)$ & $0.8(0.2-3.3)$ & $0.8(0.2-3.0)$ \\
\hline No & ref. & ref & ref. & ref \\
\hline \multicolumn{5}{|l|}{ Casual sex partner injects } \\
\hline Yes & $1.1(0.8-1.5)$ & $1.8(0.5-7.1)$ & $0.5(0.1-2.6)$ & $0.4(0.1-2.2)$ \\
\hline No & ref. & ref & ref. & ref \\
\hline \multicolumn{5}{|l|}{ Was ever paid for sex } \\
\hline Yes & $1.3(0.9-1.8)$ & $2.6(1.2-5.7)$ & $12.2(3.7-40)$ & $5.2(1.0-27)$ \\
\hline No & ref. & ref & ref. & ref \\
\hline \multicolumn{5}{|l|}{ Multiple sex partners } \\
\hline$>=2$ sex partners & $0.8(0.4-1.6)$ & $0.7(0.3-1.5)$ & $0.9(0.5-1.8)$ & $0.7(0.3-1.6)$ \\
\hline one sex partner & Ref & ref & ref & ref \\
\hline \multicolumn{5}{|l|}{ Condom with regular partner } \\
\hline Yes (consistent) & $0.9(0.7-1.4)$ & $1.0(0.7-1.4)$ & $1.9(0.4-4.6)$ & $1.5(0.5-4.5)$ \\
\hline No & ref. & ref & ref & ref \\
\hline \multicolumn{5}{|l|}{ Condom with casual partner } \\
\hline Yes (consistent) & $1.4(0.6-3.0)$ & $1.2(0.6-2.6)$ & $10.4(1.9-57)$ & $8.0(1.1-60)$ \\
\hline No & $\begin{array}{l}1.47 .0-01 \\
\text { ref. }\end{array}$ & $\begin{array}{c}1.2(0.0-2.0) \\
r e f\end{array}$ & $\begin{array}{l}10.4(1.07) \\
r e f\end{array}$ & $\begin{array}{l}0.01+.00) \\
r e f\end{array}$ \\
\hline
\end{tabular}

Table 4:(1) Odds ratio (OR) with $95 \%$ confidence intervals $(95 \% \mathrm{Cl}$ ) refer to primary Amphetamine-Type Stimulant (ATS) versus opioids (reference group). (2) Multivariable models were adjusted for age, sex, education, duration of injecting, needle/syringe programme (NSP), drug /substitution treatment, needles/syringes (N/S) confiscated (and living arrangements in St. Petersburg). Statistically significant results at the $\alpha<0.05$ are marked in bold. (3) Sexual risk in the last 6 months. 
TavitianExley_2017_ATS_injection_HIV risk_2EEurCities_IJDPM_REV1807_NTC.docx

Table 6. Associations between ATS injection and serological markers (Kohtla-Järve, St. Petersburg)

\begin{tabular}{|c|c|c|c|c|}
\hline \multirow{2}{*}{$\begin{array}{l}\text { SEROLOGICAL MARKERS }{ }^{(3)} \\
\text { (reference: opioid injectors) }\end{array}$} & \multicolumn{2}{|c|}{ Kohtla-Järve - ATS injectors ( $n=195)$} & \multicolumn{2}{|c|}{ St. Petersburg - ATS injectors $(n=27)$} \\
\hline & $\mathrm{OR}^{(1)} 95 \% \mathrm{Cl}$ & $\mathrm{aOR}^{(2)} 95 \% \mathrm{Cl}$ & $\mathrm{OR}^{(1)} 95 \% \mathrm{Cl}$ & $\mathrm{aOR}^{(2)} 95 \% \mathrm{Cl}$ \\
\hline \multicolumn{5}{|l|}{ HIV status } \\
\hline Positive & $0.4(0.3-0.6)$ & $0.6(0.5-0.8)$ & $0.2(0.1-0.4)$ & $0.3(0.1-0.7)$ \\
\hline Negative & ref & ref & ref & ref \\
\hline \multicolumn{5}{|l|}{ Hepatitis C } \\
\hline HCV reactive & $0.3(0.2-0.4)$ & $0.5(0.3-0.6)$ & Not collected & Not collected \\
\hline Non-reactive & ref. & ref & - & - \\
\hline \multicolumn{5}{|l|}{ HSV-2 status } \\
\hline Positive & $1.0(0.6-1.6)$ & $1.2(0.7-2.0)$ & Not collected & Not collected \\
\hline Negative & ref. & ref & - & - \\
\hline
\end{tabular}

Table 5: (1) Odds ratio (OR) with $95 \%$ confidence intervals $(95 \% \mathrm{Cl})$ refer to primary Amphetamine-Type Stimulant (ATS) versus opioids (reference group). (2) Multivariable models were adjusted for age, sex, education, duration of injecting, needle/syringe programme (NSP), drug /substitution treatment, needles/syringes (N/S) confiscated (and living arrangements in St.

Petersburg). Statistically significant results at the $\alpha<0.05$ are marked in bold. HIV= Human Immune deficiency Virus. $\mathrm{HCV}=$ Hepatitis $\mathrm{C}$ and HSV-2=Herpes Simplex Virus. 


\section{References}

Abdul-Quader, A. S., Heckathorn, D. D., McKnight, C., Bramson, H., Nemeth, C., Sabin, K., Gallagher, K., \& Des Jarlais, D. C. (2006). Effectiveness of respondent-driven sampling for recruiting drug users in New York City: findings from a pilot study. Journal of urban health : bulletin of the New York Academy of Medicine, 83, 459-476.

Ahamad, K., Hayashi, K., Nguyen, P., Dobrer, S., Kerr, T., Schütz, C. G., Montaner, J. S., \& Wood, E. (2015). Effect of low-threshold methadone maintenance therapy for people who inject drugs on HIV incidence in Vancouver, BC, Canada: an observational cohort study. The Lancet HIV.

Baker, A., Kochan, N., Dixon, J., Wodak, A., \& Heather, N. (1994). Drug use and HIV risktaking behaviour among injecting drug users not currently in treatment in Sydney, Australia. Drug and Alcohol Dependence, 34, 155-160.

Bao, Y. P., Liu, Z. M., Lian, Z., Li, J. H., Zhang, R. M., Zhang, C. B., Hao, W., Wang, X. Y., Zhao, M., Jiang, H. F., Yan, S. Y., Wang, Q. L., Qu, Z., Zhang, H. R., Wu, P., Shi, J., \& Lu, L. (2012). Prevalence and correlates of HIV and HCV infection among amphetamine-type stimulant users in 6 provinces in China. Journal of Acquired Immune Deficiency Syndromes, 60, 438-446.

Booth, R. E., Lehman, W. E. K., Kwiatkowski, C. F., Brewster, J. T., Sinitsyna, L., \& Dvoryak, S. (2008). Stimulant injectors in Ukraine: The next wave of the epidemic? AIDS and behavior, 12, 652-661.

Braine, N., Des Jarlais, D. C., Goldblatt, C., Zadoretzky, C., \& Turner, C. (2005). HIV risk behavior among amphetamine injectors at U.S. syringe exchange programs. AIDS Education and Prevention, 17, 515-524.

Brecht, M.-L., Huang, D., Evans, E., \& Hser, Y.-I. (2008). Polydrug use and implications for longitudinal research: Ten-year trajectories for heroin, cocaine, and methamphetamine users. Drug and Alcohol Dependence, 96, 193-201.

Buster, M. C. A., Witteveen, E., Prins, M., Van Ameijden, E. J. C., Schippers, G., \& Krol, A. (2009). Transitions in drug use in a new generation of problem drug users in amsterdam: A 6-Year Follow-Up Study. European Addiction Research, 15, 179-187.

Cepeda, J. A., Niccolai, L. M., Lyubimova, A., Kershaw, T., Levina, O., \& Heimer, R. (2015). High-risk behaviors after release from incarceration among people who inject drugs in St. Petersburg, Russia. Drug and Alcohol Dependence, 147, 196-202.

Crofts, N., \& Aitken, C. K. (1997). Incidence of bloodborne virus infection and risk behaviours in a cohort of injecting drug users in Victoria, 1990-1995. Medical Journal of Australia, 167, 17-20.

Darke, S. (1998). Self-report among injecting drug users: A review. Drug and Alcohol Dependence, 51, 253-263.

Darke, S., Kaye, S., McKetin, R., \& Duflou, J. (2008). Major physical and psychological harms of methamphetamine use. Drug and Alcohol Review, 27, 253-262.

Darke, S., Ross, J., Cohen, J., Hando, J., \& Hall, W. (1995). Injecting and sexual risk-taking behaviour among regular amphetamine users. AIDS Care - Psychological and SocioMedical Aspects of AIDS/HIV, 7, 19-26.

Degenhardt, L., Baxter, A. J., Lee, Y. Y., Hall, W., Sara, G. E., Johns, N., Flaxman, A., Whiteford, H. A., \& Vos, T. (2014). The global epidemiology and burden of psychostimulant dependence: findings from the Global Burden of Disease Study 2010. Drug and Alcohol Dependence, 137, 36-47.

Degenhardt, L., Mathers, B. M., Wirtz, A. L., Wolfe, D., Kamarulzaman, A., Carrieri, M. P., Strathdee, S. A., Malinowska-Sempruch, K., Kazatchkine, M., \& Beyrer, C. (2014). What has been achieved in HIV prevention, treatment and care for people who inject drugs, 2010-2012? A review of the six highest burden countries. International Journal of Drug Policy, 25, 53-60.

Des Jarlais, D. C., Paone, D., Milliken, J., Turner, C. F., Miller, H., Gribble, J., Shi, Q., Hagan, H., \& Friedman, S. R. (1999). Audio-computer interviewing to measure risk 
behaviour for HIV among injecting drug users: A quasi-randomised trial. Lancet, 353 (9165), 1657-1661.

Des Jarlais, D. C., Perlis, T. E., Stimson, G. V., Poznyak, V., \& Collab, W. P. I. D. I. (2006). Using standardized methods for research on HIV and injecting drug use in developing/transitional countries: case study from the WHO Drug Injection Study Phase II. BMC Public Health, 6.

Dosemeci, M., Wacholder, S., \& Lubin, J. H. (1990). Does nondifferential misclassification of exposure always bias a true effect toward the null value? American Journal of Epidemiology, 132, 746-748.

Dukhovlinova, E., Masharsky, A., Toussova, O., Verevochkin, S., Solovyeva, T., Meringof, M., Paintsil, E., White, E., Barbour, R., Heimer, R., \& Kozlov, A. (2015). Two Independent HIV Epidemics in Saint Petersburg, Russia Revealed by Molecular Epidemiology. AIDS Research and Human Retroviruses, 31, 608-614.

El-Bassel, N., Strathdee, S. A., \& Sadr, W. M. E. (2013). HIV and people who use drugs in central Asia: Confronting the perfect storm. Drug and Alcohol Dependence, 132, S2S6.

Eritsyan, K., Heimer, R., Barbour, R., Odinokova, V., White, E., Rusakova, M. M., Smolskaya, T. T., \& Levina, O. S. (2013). Individual-level, network-level and citylevel factors associated with HIV prevalence among people who inject drugs in eight Russian cities: a cross-sectional study. BMJ Open, 3.

Estonia Ministry of Health. (2014). HIV in Estonia: Narrative report for Global AIDS Reporting 2014. In National Institute for Health Development (Ed.). Talinn.

European Monitoring Centre for Drugs and Addiction. Harm Reduction Overview for Estonia. Retrieved 20162016 from www.emcdda.europa.eu/country-data/harmreduction/estonia.

European Monitoring Centre for Drugs and Drug Addiction. (2010). Problem amphetamine and methamphetamine use in Europe. In Selected Issues: EMCDDA.

European Monitoring Centre for Drugs and Drug Addiction, \& Europol. (2011). Amphetamines: A European Union perspective in the global context. In J. Publications (Ed.).

European Monitoring Centre for Drugs and Drug Addiction, \& Europol. (2012). Amphetamine: a European Union perspective in the global context. Trends in Organized Crime, 15, 222-240.

European Monitoring Centre for Drugs and Drug Addiction, \& Škařupová, K. (2014). The levels of use of opioids, amphetamines and cocaine and associated levels of harm: summary of scientific evidence. In J. V. EMCDDA (D. Thanki (Ed.). Lisbon, Portugal: EMCDDA.

Fairbairn, N., Kerr, T., Buxton, J. A., Li, K., Montaner, J. S., \& Wood, E. (2007). Increasing use and associated harms of crystal methamphetamine injection in a Canadian setting. Drug and Alcohol Dependence, 88, 313-316.

Folch, C., Merono, M., \& Casabona, J. (2006). Factors associated with sharing syringes among street-recruited injecting drug users. [Spanish]. Medicina Clinica, 127 (14), 526-532.

Gleghorn, A. A., Marx, R., Vittinghoff, E., \& Katz, M. H. (1998). Association between drug use patterns and HIV risks among homeless, runaway, and street youth in Northern California. Drug and Alcohol Dependence, 51 (3), 219-227.

Grund, J.-P., Zabransky, T., Irwin, K., \& Heimer, R. (2009). Stimulant Use in Central and Eastern Europe. In Pates, R. (Richard) and Diane Riley (eds.), Interventions for Amphetamine Misuse, Wiley-Blackwell.

Harrell, P. T., Mancha, B. E., Petras, H., Trenz, R. C., \& Latimer, W. W. (2012). Latent classes of heroin and cocaine users predict unique HIV/HCV risk factors. Drug and Alcohol Dependence, 122, 220-227.

Hayashi, K., Wood, E., Suwannawong, P., Kaplan, K., Qi, J., \& Kerr, T. (2011). Methamphetamine injection and syringe sharing among a community-recruited 
sample of injection drug users in Bangkok, Thailand. Drug and Alcohol Dependence, 115 (1-2), 145-149.

Heckathorn, D. D. (1997). Respondent-driven sampling: a new approach to the study of hidden populations. Social Problems, 174-199.

Heimer, R., Lyubimova, A., Barbour, R., \& Levina, O. S. (2015). Emergence of methadone as a street drug in St. Petersburg, Russia. International Journal of Drug Policy.

Heimer, R., \& White, E. (2010). Estimation of the number of injection drug users in St. Petersburg, Russia. Drug and Alcohol Dependence, 109, 79-83.

Hosmer, D. W. L., S. (2000). Applied logistic regression. New York; Chichester: Wiley.

Johnston, L. G., Hakim, A. J., Dittrich, S., Burnett, J., Kim, E., \& White, R. G. (2016). A Systematic Review of Published Respondent-Driven Sampling Surveys Collecting Behavioral and Biologic Data. AIDS Behav.

Johnston, L. G., \& Sabin, K. (2010). Sampling hard-to-reach populations with respondent driven sampling. Methodological Innovations Online, 5, 38-48.

Jolley, E., Rhodes, T., Platt, L., Hope, V., Latypov, A., Donoghoe, M., \& Wilson, D. (2012). HIV among people who inject drugs in Central and Eastern Europe and Central Asia: A systematic review with implications for policy. BMJ Open, 2.

Kaye, S., \& Darke, S. (2000). A comparison of the harms associated with the injection of heroin and amphetamines. Drug and Alcohol Dependence, 58, 189-195.

Kirkwood, B. S., Jonathan. (2003 ). Essential Medical Statistics. In (2nd ed ed.). Oxford: John Wiley \& Sons.

Klee, H. (1993). HIV risks for women drug injectors: Heroin and amphetamine users compared. Addiction, 88, 1055-1062.

Klee, H., Faugier, J., Hayes, C., Boulton, T. O. M., \& Morris, J. (1990). AIDS-related risk behaviour, polydrug use and temazepam. British Journal of Addiction, 85, 1125-1132.

Kozlov, A. P., Shaboltas, A. V., Toussova, O. V., Verevochkin, S. V., Masse, B. R., Perdue, T., Beauchamp, G., Sheldon, W., Miller, W. C., Heimer, R., Ryder, R. W., \& Hoffman, I. F. (2006). HIV incidence and factors associated with HIV acquisition among injection drug users in St Petersburg, Russia. AIDS, 20, 901-906.

Kozlov, A. P., Skochilov, R. V., Toussova, O. V., Verevochkin, S. V., Krasnoselskikh, T. V., Malov, S. V., \& Shaboltas, A. V. (2016). HIV incidence and behavioral correlates of HIV acquisition in a cohort of injection drug users in St Petersburg, Russia. Medicine, 95, e5238.

Kral, A. H., Bluthenthal, R. N., Booth, R. E., \& Watters, J. K. (1998). HIV seroprevalence among street-recruited injection drug and crack cocaine users in 16 US municipalities. American Journal of Public Health, 88, 108-113.

Lemstra, M., Rogers, M., Thompson, A., Moraros, J., \& Buckingham, R. (2012). Risk indicators associated with injection drug use in the Aboriginal population. Aids CarePsychological and Socio-Medical Aspects of Aids/Hiv, 24, 1416-1424.

Lorvick, J., Martinez, A., Gee, L., \& Kral, A. H. (2006). Sexual and Injection Risk among Women who Inject Methamphetamine in San Francisco. Journal of urban health : bulletin of the New York Academy of Medicine, 83, 497-505.

MacArthur, G. J., Minozzi, S., Martin, N., Vickerman, P., Deren, S., Bruneau, J., Degenhardt, L., \& Hickman, M. (2012). Opiate substitution treatment and HIV transmission in people who inject drugs: Systematic review and meta-analysis. BMJ (Online), 345.

Maher, L., Li, J., Jalaludin, B., Wand, H., Jayasuriya, R., Dixon, D., \& Kaldor, J. M. (2007). Impact of a reduction in heroin availability on patterns of drug use, risk behaviour and incidence of hepatitis $C$ virus infection in injecting drug users in New South Wales, Australia. Drug and Alcohol Dependence, 89, 244-250.

Marshall, B. D. L., Kerr, T., Livingstone, C., Li, K., Montaner, J. S. G., \& Wood, E. (2008). High prevalence of HIV infection among homeless and street-involved Aboriginal youth in a Canadian setting. Harm Reduction Journal, 5.

Marshall, B. D. L., Wood, E., Shoveller, J. A., Buxton, J. A., Montaner, J. S. G., \& Kerr, T. (2011). Individual, Social, and Environmental Factors Associated with Initiating 
Methamphetamine Injection: Implications for Drug Use and HIV Prevention Strategies. Prevention Science, 12, 173-180.

Martin, M., Vanichseni, S., Suntharasamai, P., Mock, P. A., van Griensven, F., Pitisuttithum, P., Tappero, J. W., Chiamwongpaet, S., Sangkum, U., Kitayaporn, D., Gurwith, M., \& Choopanya, K. (2010). Drug use and the risk of HIV infection amongst injection drug users participating in an HIV vaccine trial in Bangkok, 1999-2003. International Journal of Drug Policy, 21, 296-301.

Mathers, B. M., Degenhardt, L., Ali, H., Wiessing, L., Hickman, M., Mattick, R. P., Myers, B., Ambekar, A., \& Strathdee, S. A. (2010). HIV prevention, treatment, and care services for people who inject drugs: a systematic review of global, regional, and national coverage. The Lancet, 375, 1014-1028.

Mathers, B. M., Degenhardt, L., Phillips, B., Wiessing, L., Hickman, M., Strathdee, S. A., Wodak, A., Panda, S., Tyndall, M., Toufik, A., Mattick, R. P., \& Reference Group to the United Nations Reference Group on HIV and Injecting Drug Use. (2008). Global epidemiology of injecting drug use and HIV among people who inject drugs: a systematic review. Lancet, 372, 1733-1745.

Mehrjerdi, Z. A. (2013). Crystal in Iran: methamphetamine or heroin kerack. Daru-Journal of Pharmaceutical Sciences, 21.

Mehrjerdi, Z. A., Abarashi, Z., Noroozi, A., Arshad, L., \& Zarghami, M. (2014). Correlates of shared methamphetamine injection among methamphetamine-injecting treatment seekers: the first report from Iran. International Journal of STD and AIDS, 25, 420427.

Molitor, F., Ruiz, J. D., Flynn, N., Mikanda, J. N., Sun, R. K., \& Anderson, R. (1999). Methamphetamine Use and Sexual and Injection Risk Behaviors Among Out-ofTreatment Injection Drug Users. The American journal of drug and alcohol abuse, 25, 475-493.

Molitor, F., Truax, S. R., Ruiz, J. D., \& Sun, R. K. (1998). Association of methamphetamine use during sex with risky sexual behaviors and HIV infection among non-injection drug users. Western Journal of Medicine, 168 (2), 93-97.

Napper, L. E., Fisher, D. G., Reynolds, G. L., \& Johnson, M. E. (2010). HIV Risk Behavior Self-Report Reliability at Different Recall Periods. AIDS and behavior, 14, 152-161.

National Institute for Health Development. (2015). HIV in Estonia: Situation, prevention, treatment, and care. In Narrative report for GARPR 2015 (pp. 23). Tallinn, Estonia.

Pates, R. (2013). Special Issue on injecting, why is this important? Journal of Substance Use, $18,1-2$.

Platt, L., Bobrova, N., Rhodes, T., Uuskula, A., Parry, J. V., Ruutel, K., Talu, A., Abel, K., Rajaleid, K., \& Judd, A. (2006). High HIV prevalence among injecting drug users in Estonia: implications for understanding the risk environment. AIDS, 20, 2120-2123.

Poundstone, K. E., Strathdee, S. A., \& Celentano, D. D. (2004). The social epidemiology of human immunodeficiency virus/acquired immunodeficiency syndrome. Epidemiologic Reviews, 26, 22-35.

Rondinelli, A. J., Ouellet, L. J., Strathdee, S. A., Latka, M. H., Hudson, S. M., Hagan, H., \& Garfein, R. S. (2009). Young adult injection drug users in the United States continue to practice HIV risk behaviors. Drug and Alcohol Dependence, 104, 167-174.

Ross, J., Darke, S., \& Hall, W. (1997). Transitions between routes of benzodiazepine administration among heroin users in Sydney. Addiction, 92, 697-705.

Saw, Y., Poudel, K., Kham, N. P., Chan, N., Cope, J., Wai, K., Tun, S., \& Saw, T. (2014). Assessment of HIV testing among young methamphetamine users in Muse, Northern Shan State, Myanmar. BMC Public Health, 14, 735.

Shearer, J., Sherman, J., Wodak, A., \& Van Beek, I. (2002). Substitution therapy for amphetamine users. Drug and Alcohol Review, 21, 179-185.

Solon, G., Haider, S., \& Wooldridge, J. (2013). What are we weighting for?(NBER Working Paper 18859). 
StataCorp. (2013). Stata survey data reference manual (Release 13). In (Stata: Release 13 ed.). StataCorp LP. College Station, TX: StataCorp.

Swe, L. A., \& Rashid, A. (2012). Prevalence of HIV and the risk behaviours among injecting drug users in Myanmar. International Journal of Collaborative Research on Internal Medicine and Public Health, 4 (1), 56-70.

Talu, A., Rajaleid, K., Abel-Ollo, K., Ruutel, K., Rahu, M., Rhodes, T., Platt, L., Bobrova, N., \& Uuskula, A. (2010). HIV infection and risk behaviour of primary fentanyl and amphetamine injectors in Tallinn, Estonia: Implications for intervention. International Journal of Drug Policy, 21, 56-63.

Tavitian-Exley, I. (2016). The relevance of polydrug use in HIV risk and associated injecting and sexual risk behaviours among people who inject drugs. Unpublished Doctoral thesis, Imperial College London, United Kingdom.

Tavitian-Exley, I., Boily, M., Heimer, R., Uusküla, A., Levina, O., \& Maheu-Giroux, M. (2017). Polydrug Use and Heterogeneity in HIV Risk Among People Who Inject Drugs in Estonia and Russia: A Latent Class Analysis. AIDS and behavior.

Tavitian-Exley, I., Vickerman, P., Bastos, F. I., \& Boily, M.-C. (2015). Influence of different drugs on HIV risk in people who inject: systematic review and meta-analysis. Addiction, 110, 572-584.

UCLA Statistical Consulting Group. Survey Data Analysis in Stata. from http://www.ats.ucla.edu/stat/stata/seminars/svy_stata_8/default.htm.

United Nations Joint Programme on AIDS. (2016). Global AIDS update. In (2016 ed.). Geneva: United Nations Joint Programme on AIDS.

United Nations Joint Programme on HIV and AIDS. (2013). Global report: UNAIDS report on the global AIDS epidemic 2013. In UNAIDS (Ed.). Geneva, Switzerland: United Nations Joint Programme on HIV and AIDS.

United Nations Joint Programme on HIV and AIDS. (2014). Global report: UNAIDS report on the global AIDS epidemic 2014. In UNAIDS (Ed.). Geneva, Switzerland: United Nations Joint Programme on HIV and AIDS.

United Nations Office on Drugs and Crime. (2010). Myanmar Situation Assessment on Amphetamine-Type Stimulants. In R. a. T. S. P. UNODC Global Global Synthetics Monitoring: Analyses (Ed.), Global Global Synthetics Monitoring: Analyses, Reporting and Trends (SMART) Programme: UNODC.

United Nations Office on Drugs and Crime. (2012). World Drug Report 2012. In Research and Trend Analysis Branch (Ed.), United Nations publication. Vienna: UNODC.

United Nations Office on Drugs and Crime. (2014). World Drug Report 2014. In Research and Trend Analysis Branch (Ed.), United Nations publication. Vienna: UNODC.

United Nations Office on Drugs and Crime. (2015a). Trends and Patterns of Amphetaminetype Stimulants and New Psychoactive Substances. In UNODC Regional Office for Southeast Asia and the Pacific (Ed.), The Challenge of Synthetic Drugs in East and South-East Asia and Oceania (pp. 45). Vienna: United Nations Office on Drugs and Crime,

United Nations Office on Drugs and Crime. (2015b). World Drug Report 2015. In Research and Trend Analysis Branch (Ed.), United Nations publication. Vienna: UNODC.

United Nations Office on Drugs and Crime. (2016). World Drug Report 2016. In Research and Trend Analysis Branch (Ed.), United Nations publication. Vienna: UNODC.

Uuskula, A., Des Jarlais, D. C., Raag, M., Pinkerton, S. D., \& Feelemyer, J. (2015). Combined prevention for persons who inject drugs in the HIV epidemic in a transitional country: the case of Tallinn, Estonia. AIDS Care, 27, 105-111.

Uuskula, A., Raag, M., Vorobjov, S., Ruutel, K., Lyubimova, A., Levina, O. S., \& Heimer, R. (2015). Non-fatal overdoses and related risk factors among people who inject drugs in St. Petersburg, Russia and Kohtla-Jarve, Estonia. BMC Public Health, 15.

Uuskula, A., Rajaleid, K., Talu, A., Abel-Ollo, K., \& Des Jarlais, D. C. (2013). A decline in the prevalence of injecting drug users in Estonia, 2005-2009. International Journal of Drug Policy, 24, 312-318. 
Van Ameijden, E. J. C., Van den Hoek, J. A. R., Hartgers, C., \& Coutinho, R. A. (1994). Risk factors for the transition from noninjection to injection drug use and accompanying AIDS risk behavior in a cohort of drug users. American Journal of Epidemiology, 139 (12), 1153-1163.

Volz, E., \& Heckathorn, D. D. (2008). Probability Based Estimation Theory for Respondent Driven Sampling. Journal of Official Statistics, 24, 79-97.

Volz, E., Wejnert, C., Cameron, S., Spiller, M., Barash, V., Degani, I., \& Heckathorn, D. D. (2012). Respondent-driven sampling analysis tool (RDSAT) version 7.1. Ithaca: Cornell University.

Vorobjov, S., Uuskula, A., Abel-Ollo, K., Talu, A., Ruutel, K., \& Des Jarlais, D. C. (2009). Comparison of injecting drug users who obtain syringes from pharmacies and syringe exchange programs in Tallinn, Estonia. Harm Reduction Journal, 6.

Walsh, N., \& Maher, L. (2013). HIV and HCV among people who inject drugs in Central Asia. Drug and Alcohol Dependence, 132, S37-S40.

White, R. G., Hakim, A. J., Salganik, M. J., Spiller, M. W., Johnston, L. G., Kerr, L., Kendall, C., Drake, A., Wilson, D., Orroth, K., Egger, M., \& Hladik, W. (2015). Strengthening the Reporting of Observational Studies in Epidemiology for respondent-driven sampling studies: "STROBE-RDS" statement. Journal of Clinical Epidemiology.

World Health Organization. (2013). Global update on HIV treatment 2013: results, impact and opportunities. 